\title{
AN INNOVATIVE ASSESSMENT METHOD TO ESTABLISH EMPLOYABILITY MAP BASED ON STUDENTS' LEARNING PORTFOLIO
}

\author{
Shu-Chen Cheng, Shing-Lin Chang \\ Southern Taiwan University of Science and Technology, Taiwan \\ E-mail: kittyc@stust.edu.tw, slchang@stust.edu.tw
}

\begin{abstract}
This research focuses on the approach adopted by a university of science and technology in Taiwan (hereinafter the university) to develop students' employability indices and to explore the questionnaire analyses. The university developed the "Employability Map; E-Map" by weighting the learning hours, which was used to evaluate students' various employability items over the course of their schooling. Considering it not so appropriate to use students' credits on courses to be the standard of judgment, the Department of Computer Science \& Information Engineering (hereinafter the department) proposed an innovative method to convert the E-Map of weighting by learning achievement to conduct assessments that is more reflection students' employability indices for graduate, and analyzed the questionnaires of alumni and their employers' various core employability indices. From those questionaires, finding the graduating students and alumni are lack of self-confidentce. The statistical data shall serve as a reference for guiding students at course selection, as well as improving department courses and planning.

Keywords: employability indices, employability map, learning achievement, learning portfolio.
\end{abstract}

\section{Introduction}

Due to the impacts of global informationization and the knowledge economy as well as rapid changes in the labor market and the popularization of higher education, university graduates of this generation not only face fierce international competition and challenges arising from rapid changes in the industrial structure when they enter the workplace, but it is also necessary for them to be able to continue to absorb new knowledge and adapt to non-lifetime employment patterns and non-linear career development paths. Faced with this era of challenges, university students are suggested to possess employability skills that meet the new economic requirements to successfully enter the workplace and achieve sustainable development.

In order to improve students' employability skills, the university used weighting by learning hours to develop the Employability Map (E-Map) that serves as the basis for course planning, teachers' teaching content improvement, and students' course selection. The system accordingly distributed course-learning results to various employability indices in order to assist students in gaining an insight into course implications, course selection, and course study. Complemented by the E-Map, comprehensive course planning and assistance are provided. Students may cultivate their own employability with a radar chart as a guide, thereby developing employment competency with personal professional characteristics. The E-Map developed through weighting by learning hours is based on students' credits earned from completing all the courses, which reflects various employability indices; however, it is less capable of reflecting students' overall learning employment competency. Hence, the department employed the E-Map of weighting by learning achievement and conducted a questionnaire survey on the 
Shu-Chen CHENG, Shing-Lin CHANG. An innovative assessment method to establish employability map based on students' learning portfolio

\author{
PROBLEMS \\ OF EDUCATION \\ IN THE $21^{\text {st }}$ CENTURY \\ Vol. 77, No. 1, 2019 \\ 210 \\ core employability of graduating students, alumni, and alumni' employees, thereby gaining an \\ insight into students' core employability performance and the skill requirements of the industry, \\ carrying out analysis, and serving as a reference for revising course contents or adding and \\ modifying subjects.
}

\title{
Literature Review
}

Due to the relatively stagnant economic growth in recent years (Alana 2016), young people's unemployment rates have remained high, which have in turn affected talent training programs in tertiary education in different countries. In recent decades, there has been a great deal of concern over the employment of university graduates at home and abroad. Therefore, many literatures covered discussions of related topics (Jackson, 2014; Tholen, 2015; Turner, 2014; Wu, Tsai, \& Chen, 2014). In order for the Taiwan government to cope with the high level of tertiary manpower demand for social development, there has been a significant increase in the number of tertiary institutions. This has changed the elite essence of university education, heading towards the development direction of mass-orientation and popularization. More than ever, this development reflects a greater need for tertiary professionals, in order to facilitate social, economic, and technological development. Hence, the enhancement of university students' employability related measures is regarded as the key indicator for evaluating Taiwan's educational institutions.

However, the definition of "employability" tends to change with time and background. For example, in the early stages, Beveridge (1909) suggested that employability should be used to determine individuals with the ability to work. According to the definition of Harvey, Locke and Morey (2002), employability is the ability to get a job, keep it, and do well at it, which is developed through learning; in other words, it is the ability to obtain a job from the labor market and continue until completion. Yorke (2004) defined employability as the combination of achievement, skill, comprehension, and personal characteristics, which gives graduates greater access to employment opportunities and enables them to achieve success in their chosen occupations for graduates' own gain and to the benefit of the labor force, society, and economy. Nevertheless, most researchers deemed employment competency complex and multi-dimensional, and thus it should not be simplified to try to define it (Harvey, 2005; Holmes, 2006; Rae, 2007; Rothwell \& Arnold, 2007). Hugh-Jones, Sutherland and Cross (2006) said that this complexity is due to the fact that employability must be viewed from three aspects, namely, employers, students, and higher education. Tymon (2013) pointed out that students refer not only to graduates. He recommends employment-related information and skills be provided through higher education. Guilbert, Bernaud, Gouvernet and Rossier (2016) recently defined employability as the ability to obtain a suitable job or retain employment, which includes interrelatedness of the government and education policies, corporate organizations, individual traits, as well as dynamic social, economic, cultural, and technological development.

At present, most universities in Taiwan have joined the evaluation system of the Institute of Engineering Education Taiwan (IEET, 2018). According to IEET's definition of core employment competency achievement index, the only principle is to have "clear, specific, and testable contents". In this paper, with the university department adopted as the example, the core employability indices set up after years of evaluation and modifications were proposed. Additionally, the results of employability assessment questionnaires of employers of alumni, alumni graduated for 3-5 years, and graduating students were analyzed to view all of the core employability competencies and to inspect which areas need strengthening courses and to discuss at the department's expert consultation meetings. The course contents, levels, and learning hours were adjusted to ensure students to achieve better employment competency and meet companies' needs. 
Shu-Chen CHENG, Shing-Lin CHANG. An innovative assessment method to establish employability map based on students' learning portfolio

\section{Research Methodology}

Setup of Employability Indices

The student employability index system is usually a "capacity-oriented performance assessment and display" system, which divides traditionally one-dimensional learning performance into multi-dimensional capacity indices according to various employment competency items required by industries. A radar chart is used to present students' learning effectiveness in various employability items. In order to present students' learning effectiveness in employability, the university adopted weighting by learning hours to represent students' employability (i.e. E-Map). However, in conjunction with the respective departments' schoolbased curriculum planning, the department developed the E-Map weighting by learning achievement that differed from E-Map weighting by learning hours as the basis for curriculum planning, teachers' teaching content improvement, and students' course selection. At the same time, it can also be used to help students timely examine the degree of employability completion over their period of study.

In order to implement employability issues of technological and vocational colleges that have been focuses of the Ministry of Education, Taiwan (R.O.C.) (hereinafter MOE) and to achieve the vision of enhancing young people's employment competency, the research takes into consideration of eight core employability items set up by the MOE (communication skills, teamwork skills, problem solving skills, original and enterprising skills, planning and organizational skills, self-management skills, learning skills, and technological skills), the department's existing IEET engineering and technological education certification competency indicators, the current youth employability demand of the department, and other information. Through the department's expert consultation meetings, teachers discussed to set up the department's core employment competency indices. Table 1 shows the core employability index contents and abbreviations set up by the department. The department's core employability index planning is divided into two dimensions: "professional competency" and "general knowledge competency", with five employability indices set for each dimension. In particular, the professional competency includes engineering knowledge, information competency, practical competency, and plan integration, and foreign language competency. The remaining indices belong under general knowledge competency. These indices were used to cover student employability nurtured through campus courses and related education learning activities. 
Shu-Chen CHENG, Shing-Lin CHANG. An innovative assessment method to establish employability map based on students' learning portfolio

PROBLEMS

OF EDUCATION

IN THE $21^{\text {st }}$ CENTURY

Vol. 77 , No. 1, 2019

Table 1. Core employability indices and abbreviations.

\begin{tabular}{|c|c|c|}
\hline Number & Core employability indices & Abbreviations of indices \\
\hline 1 & $\begin{array}{l}\text { Competency in applied mathematics, science, and engineering } \\
\text { knowledge }\end{array}$ & Engineering knowledge (E.K.) \\
\hline 2 & $\begin{array}{l}\text { Competency in design and implementation of experiments and } \\
\text { interpreting and analyzing data interpretation }\end{array}$ & Information competency (I.C.) \\
\hline 3 & $\begin{array}{l}\text { Software and hardware tools and information technology } \\
\text { competency needed for engineering practice implementation }\end{array}$ & Practical competency (P.C.) \\
\hline 4 & $\begin{array}{l}\text { Competency in achieving component, integration system, or } \\
\text { planning processes }\end{array}$ & Planning and integration (P.I.) \\
\hline 5 & $\begin{array}{l}\text { Communication skills and competency in oral expression and } \\
\text { written reports }\end{array}$ & Report communication (R.C.) \\
\hline 6 & $\begin{array}{l}\text { Competency in formulating ideas, coordinating and solving engi- } \\
\text { neering problems }\end{array}$ & Identification of ideas (I.I.) \\
\hline 7 & $\begin{array}{l}\text { Competency in project management, effective communication, } \\
\text { and teamwork }\end{array}$ & Management cooperation (M.C.) \\
\hline 8 & Literary in professional responsibility and professional ethics & Professional ethics (P.E.) \\
\hline 9 & Competency in foreign language use & Foreign language competency (F.L.C.) \\
\hline 10 & $\begin{array}{l}\text { Competency in understanding the current situation of industrial } \\
\text { development, cultivation of self-improvement, and adaptation to } \\
\text { social environment changes }\end{array}$ & Social humanities (S.H.) \\
\hline
\end{tabular}

\section{E-Map of Weighting by Learning Hours}

Since students' employability cultivation is mostly derived from courses, it was reasonable to observe students' employability skills through course training. How do regular universities calculate students' employability? The university department was adopted as the example. First, the employability indices and weights cultivated through course training were listed by their respective departments or centers, each course covering about 4-6 employability indices. The weight of every subject was distributed using the sum of 100. As shown in the example in Table 2, the object-oriented programming was used as the example to explain if a student passes a particular subject, since three credits are allotted for the subject, it occupies $20 \%$ of engineering knowledge. Hence, the competency index corresponding to the engineering knowledge is:

$$
3 \text { (Credits) } \times 20 \%=0.6
$$

Using this equation, the scores of all the courses in the respective competency indices were calculated. Finally, the respective competency indices were summed up to derive employability indices obtained by the students in the department. Every student differed in the courses taken, thus the variations in the employability indices. Since every student in the department took up different courses and that the general knowledge course they took varied 
Shu-Chen CHENG, Shing-Lin CHANG. An innovative assessment method to establish employability map based on students' learning portfolio

vastly, only the employability radar chart constituted through professional field training in the

PROBLEMS

OF EDUCATION

IN THE $21^{\text {st }}$ CENTURY

Vol. 77, No. 1, 2019

department was included in the discussion. From the grades every semester, the university added up the competencies of the courses taken up and passed by the students and converted them into employability radar chart that serves as a reference for students during course planning and course selection. However, the department only targeted the E-Map presented by the professional subjects for discussion. This type of computation showed the total score of the respective indices upon student graduation, which is the total professional score upon graduation. As for how the students could use the visualized radar chart to gain an insight into whether their competency met the department requirements, the distribution of the courses completed by the students was used to calculate the personal employability radar chart (as exemplified by an anonymous second-year student shown in Figure 1). There is no basic radar chart for reference. In order to provide students with a reference point for course selection, all the graduates who successfully graduated from the department were adopted as samples totaling 104. The employability indices of all the professional subjects they took up and passed were added and averaged to obtain the employability radar chart of professional courses belonging to the department (as shown in Figure 2). The data obtained shall serve as a reference for the third or second-year students, enabling them to see in which dimensions they were deficient. The subjects occupying higher ratios with respect to certain competencies were also provided (See Table 2) to serve as a reference for students during course selection. For example, when a student finished the second-year, student and his/her practical competency did not reach 7.8 but was interested on practice course, he/she would be advised to choose the courses which have high-ratio practical competency, such as "Object-Oriented Programming". This course in terms of engineering knowledge, information competency, and practical competency, has $20 \%$ weighting, respectively. On the other hand, the data shall also be provided as a reference during department course planning to determine whether the ratios of courses with respect to certain competencies need to be increased or decreased.

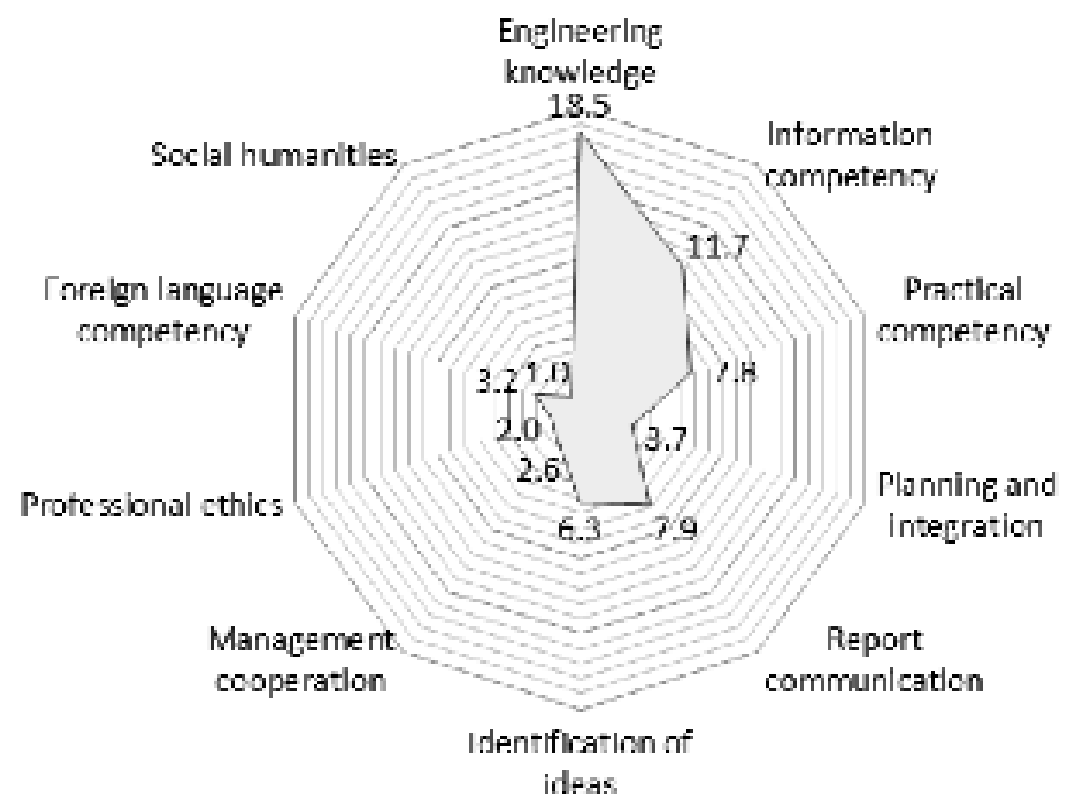

Figure 1. Employability radar chart of an anonymous student who completed professional courses allotted for second-year student. 
Shu-Chen CHENG, Shing-Lin CHANG. An innovative assessment method to establish employability map based on students' learning portfolio

PROBLEMS

OF EDUCATION

IN THE $21^{\text {st }}$ CENTURY

Vol. 77, No. 1, 2019

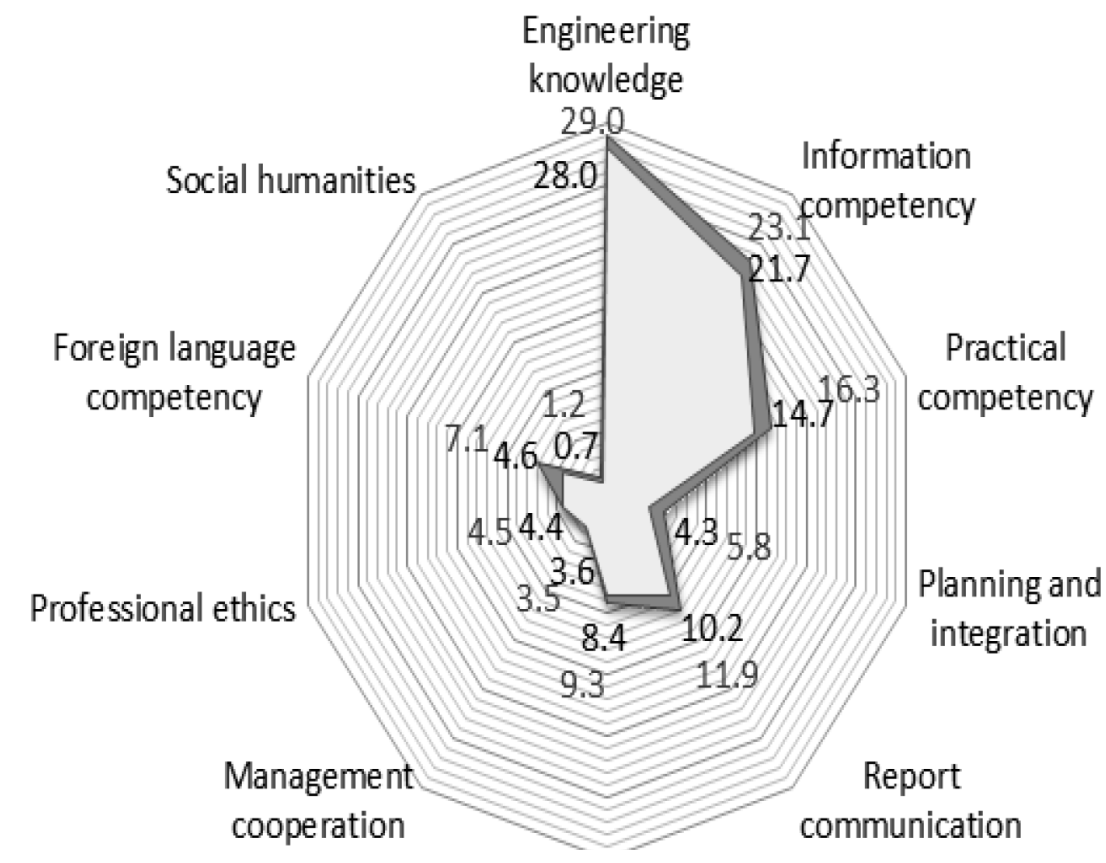

Figure 2. Employability radar chart of average professional courses upon graduation from the department.

Table 2. Distribution of certain competencies exceeding $\mathbf{2 0} \%$.

\begin{tabular}{|c|c|}
\hline Engineering knowledge & Information competency \\
\hline $\begin{array}{l}\text { Foundations of Computer Vision (30\%) } \\
\text { Programming of Hardware Description Language (30\%) } \\
\text { Practical Programming for Problem Solving (25\%) } \\
\text { Information Security }(25 \%) \\
\text { Computer Game Programming }(25 \%) \\
\text { System Programming (40\%) }\end{array}$ & $\begin{array}{l}\text { Practical Programming for Problem Solving (25\%) } \\
\text { System Programming (20\%) } \\
\text { Object-Oriented Programming (20\%) } \\
\text { JAVA Programming }(25 \%) \\
\text { Introductory to Cryptography }(30 \%) \\
\text { Wed Development Topics }(25 \%) \\
\ldots\end{array}$ \\
\hline Practical competency & Planning and integration \\
\hline $\begin{array}{l}\text { Practical Programming for Problem Solving (25\%) } \\
\text { Information Security }(25 \%) \\
\text { Computer Game Programming }(25 \%) \\
\text { Object-Oriented Programming }(20 \%) \\
\text { JAVA Programming }(25 \%)\end{array}$ & $\begin{array}{l}\text { User experience design ( } 30 \%) \\
\text { Practical Programming for Problem Solving (25\%) } \\
\text { Sofeware Engineering (30\%) }\end{array}$ \\
\hline
\end{tabular}

\section{Quantitative Core Competency Indices}

In Equation (1), weighting by learning hours was used to calculate employability indices. It shows that the higher the credits students obtained, the higher the corresponding competency indices. The results may seem reasonable, but as far as the department is concerned, the data 
is less helpful in competency statistical analysis, as the indices only take "passing or not" into account. However, the passing scores of 90 and 60 for the same subject should lead to students' differed competency scores for absorbing a particular subject. In fact, with this type of calculation, as long as students complete credits for graduation, their respective competency indices will possibly reach the standard of the employability radar chart. As shown in Figure 3 , the respective competencies of students ranking first and fortieth in class approximate mean value (Figure 2). They both gain credits of the course, which cannot serve as the basis for judging students' career. Therefore, this research started with the course questionnaire to design a questionnaire for employability indices to be obtained from course training using the level of understanding or perception of students and converted it into various index scores to objectively evaluate students' employability indices. This is an innovative assessment method.

First, in order to understand the class commencement situation of the university department and evaluate whether or not the students possessed the core employment competency upon graduation, a questionnaire survey was conducted on the graduating students, alumni and alumni's employers, here valid samples were 97, 111 and 70, respectively. In particular, the graduating students were administered questionnaires in two dimensions: first, targeting core competencies, direct core competency questions were asked for students to fill out (abbreviated as the direct questionnaire). The students conducted a self-assessment on the core competencies based on knowledge learned in school. For instance, with "engineering knowledge" as the core competency, the question content is: "Competency in the application of mathematics, science, and engineering knowledge". The 5-point Likert scale was adopted as the scoring method ( $5=$ highly agree; $4=$ agree; $3=$ average; $2=$ disagree; $1=$ highly disagree), with I number of graduating student samples, $\mathrm{K}$ items of competency indices, $\mathrm{C}_{-} \mathrm{ik}$ as the score of the kth item of competency indicators self-assessed by student $\mathrm{i}$, and $\mathrm{M}_{-} \mathrm{k}$ as the mean score for the kth item of competency indices. The equation is as follows:

$$
M_{k}=\frac{1}{I} \sum_{i=1}^{I} C_{i k}, 1 \leq k \leq K
$$

Another assessment targets a view on the four-year courses taken by the graduating students. Every year, the department committee chooses 10-12 representative required (optional) subjects to conduct a questionnaire assessment, which is for evaluating graduates' core competencies (abbreviated as the course questionnaire). First of all, the course teacher proposed what core competencies and ratios the course wants to cultivate, and then discussed with the curriculum committee to revise. Finally, according to the given core competencies and ratios, appropriate questions of the course questionnaire are implemented. In principle, one question is given for every $10 \%$ occupied by a core competency. Take the object-oriented programming in Table 2 for example, there are two questions in the questionnaire on related knowledge since engineering knowledge occupies 20\% (See Table 3), and the evaluation is based on the students' degree of perception towards the knowledge. The 5-point Likert scale was the scoring method adopted. The subject-learning situation of the graduating students in four years served as the basis for evaluating the graduating students' actual core competency effectiveness. There were $I$ number of graduating student samples, $J$ number of subjects asked, and $K$ items of competency indices were set. $r_{j k}$ is the ratio of th item of competency indices in th subject; $r_{k}=\sum_{j=1}^{J} r_{j k}$ is the ratio sum of the th item of competency indices; is the score sum of self-assessed th item of competency indices of the $k$ th student in the $i$ th subjects; $C_{i j k}$ is the weighted average score of the th item of competency indices. The equation is as follows:

$$
A_{k}=\sum_{j=1}^{J}\left[\left(\frac{1}{I} \times \frac{1}{r_{j k} \times 10} \sum_{i=1}^{I} C_{i j k}\right) \times \frac{r_{j k}}{r_{k}}\right]=\frac{1}{10 r_{k} I} \sum_{j=1}^{J} \sum_{i=1}^{I} C_{i j k}, 1 \leq k \leq K,(3)
$$


Shu-Chen CHENG, Shing-Lin CHANG. An innovative assessment method to establish employability map based on students' learning portfolio

OF EDUCATION

IN THE $21^{\text {st }}$ CENTURY Vol. 77, No. 1, 2019

the mean value and standard deviation of every competency index were obtained, and the difference between two samples means was also tested in order to analyze differences in the direct questionnaire (Equation 2) and the course questionnaire (Equation 3) comprising graduating students' respective core competencies.

In order to gain an insight into whether or not alumni possess sufficient core competency in the workplace, enough to cope with work in the industry upon graduation, as well as the relevance between the nature of work and the core competency cultivated in this department, the statistical results of the alumni's questionnaires shall serve as an important reference for course planning. The alumni's questionnaire contents included: requesting alumni to evaluate whether or not the department education provides such core competency during the period of enrollment and the relevance between the core competency and the current work needs. The alumni who had graduated for 3-5 years were collected as the questionnaire samples. Equation 2 was adopted to obtain the mean values, and a test was carried out to determine the difference between the two population means.

In order to gain an insight into whether or not the education goals set by the department are in line with the industrial needs and employers' evaluation of whether or not the alumni possess the respective core competency, a questionnaire on the evaluation of graduates' core competency by the employers or supervisors of graduates was conducted. The survey results shall serve a reference for improving the department's course planning. Targeting the respective items of each core competency, the employers were requested to evaluate the importance of the core competencies to the company as well as whether or not the alumni possess such core competencies. Similarly, Equation 2 was adopted to obtain the mean values, and a test was carried out to determine the difference between the two population means.

Table 3. Configuration of employability index weights of different courses.

\begin{tabular}{|c|c|c|c|c|c|c|c|c|c|c|}
\hline Course Names & E.K. & I.C. & P.C. & P.I. & R.C. & I.I. & M.C. & P.E. & F.L.C & S.H. \\
\hline $\begin{array}{l}\text { Object-Oriented } \\
\text { Programming }\end{array}$ & 20 & 20 & 20 & 10 & 0 & 10 & 10 & 10 & 0 & 0 \\
\hline System Programming & 40 & 20 & 0 & 0 & 20 & 0 & 0 & 0 & 20 & 0 \\
\hline Data Structure & 20 & 30 & 20 & 0 & 10 & 0 & 20 & 0 & 0 & 0 \\
\hline $\begin{array}{l}\text { Engineering Ethics } \\
\text { and society }\end{array}$ & 20 & 0 & 0 & 0 & 20 & 0 & 20 & 0 & 10 & 30 \\
\hline $\begin{array}{l}\text { Windows Program- } \\
\text { ming }\end{array}$ & 20 & 20 & 20 & 10 & 0 & 20 & 10 & 0 & 0 & 0 \\
\hline $\begin{array}{l}\text { Network Operating } \\
\text { System }\end{array}$ & 20 & 0 & 30 & 0 & 0 & 30 & 0 & 10 & 0 & 10 \\
\hline
\end{tabular}




\title{
Table 4. Assessment questionnaire on core competency of object-oriented programming course.
}

\begin{tabular}{|c|c|c|c|}
\hline $\begin{array}{l}\text { Core } \\
\text { competency }\end{array}$ & $\begin{array}{l}\text { Assessment } \\
\text { weighting }\end{array}$ & $\begin{array}{lllll}5 & 4 & 3 & 2 & 1\end{array}$ & Item \\
\hline \multirow{2}{*}{$\begin{array}{l}\text { Engineering } \\
\text { knowledge }\end{array}$} & \multirow[b]{2}{*}{20} & $\square \square \square \square \square$ & Possess the ability to write object types \\
\hline & & $\square \square \square \square \square$ & Understand object inheritance purposes and applications \\
\hline \multirow{2}{*}{$\begin{array}{l}\text { Information } \\
\text { competency }\end{array}$} & \multirow[b]{2}{*}{20} & $\square \square \square \square \square$ & Understand $\mathrm{C}++$ program design language \\
\hline & & $\square \square \square \square \square$ & $\begin{array}{l}\text { Understand C++ object construction and decomposition } \\
\text { concepts }\end{array}$ \\
\hline \multirow{2}{*}{$\begin{array}{l}\text { Practical } \\
\text { competency }\end{array}$} & \multirow{2}{*}{20} & $\square \square \square \square \square$ & $\begin{array}{l}\text { Understand three types of access permissions: CC++ private, } \\
\text { open and protect }\end{array}$ \\
\hline & & $\square \square \square \square \square$ & Understand $\mathrm{C}++$ index operations \\
\hline $\begin{array}{l}\text { Planning and } \\
\text { integration }\end{array}$ & 10 & $\square \square \square \square \square$ & Possess the ability to construct program processes \\
\hline $\begin{array}{l}\text { Identification } \\
\text { of ideas }\end{array}$ & 10 & $\square \square \square \square \square$ & Possess the ability to solve basic program design problems \\
\hline $\begin{array}{l}\text { Management } \\
\text { cooperation }\end{array}$ & 10 & $\square \square \square \square \square$ & $\begin{array}{l}\text { Possess the ability to work with others in writing software } \\
\text { programs }\end{array}$ \\
\hline $\begin{array}{l}\text { Professional } \\
\text { ethics }\end{array}$ & 10 & $\square \square \square \square \square$ & Understand the job contents of software engineers \\
\hline
\end{tabular}

\section{E-Map of Weighting by Learning Achievement}

Figures 3-4 present the E-Map of weighting by learning hours and weighting by learning achievement, respectively. Both diagrams were obtained from the graduating class of the department, specifically the performance of two students ranking first and fortieth in class after completing the credits for graduation and in self-assessment of the course questionnaire. In Figure 3, Equation 1 is used to convert the courses passed on graduation into core competencies, which are added, thus the proximity of both students in terms of their respective competencies. The credits earned by the students ranking first and fortieth in class were 151 and 142 credits respectively. Therefore, given that these two people's credits for graduation are close, their employability radar charts are also similar. It is even possible that the student trailing behind in rank obtains a higher score than the student who is ahead in class ranking. This shows that the E-Map weighting by learning hours is less capable of reflecting students' core competency performance. In Figure 4, Equation 3 is used to convert subjects the students passed into various core competency scores through the course questionnaire, which is used to evaluate the course questionnaire radar chart of students' employability indices. Figure 4 shows the respective competency indices presented in the 5-point scale. A higher score indicates the students' higher comprehension and perception. It is clear that the performance of the student ranking fortieth in class is inferior to the student ranking first. Of course, it is merely an aggregate representation. The figure shows that the student ranked fortieth approximates the student ranked first in management cooperation. 
Shu-Chen CHENG, Shing-Lin CHANG. An innovative assessment method to establish employability map based on students' learning portfolio

PROBLEMS

OF EDUCATION IN THE $21^{\text {st }}$ CENTURY Vol. 77, No. 1, 2019

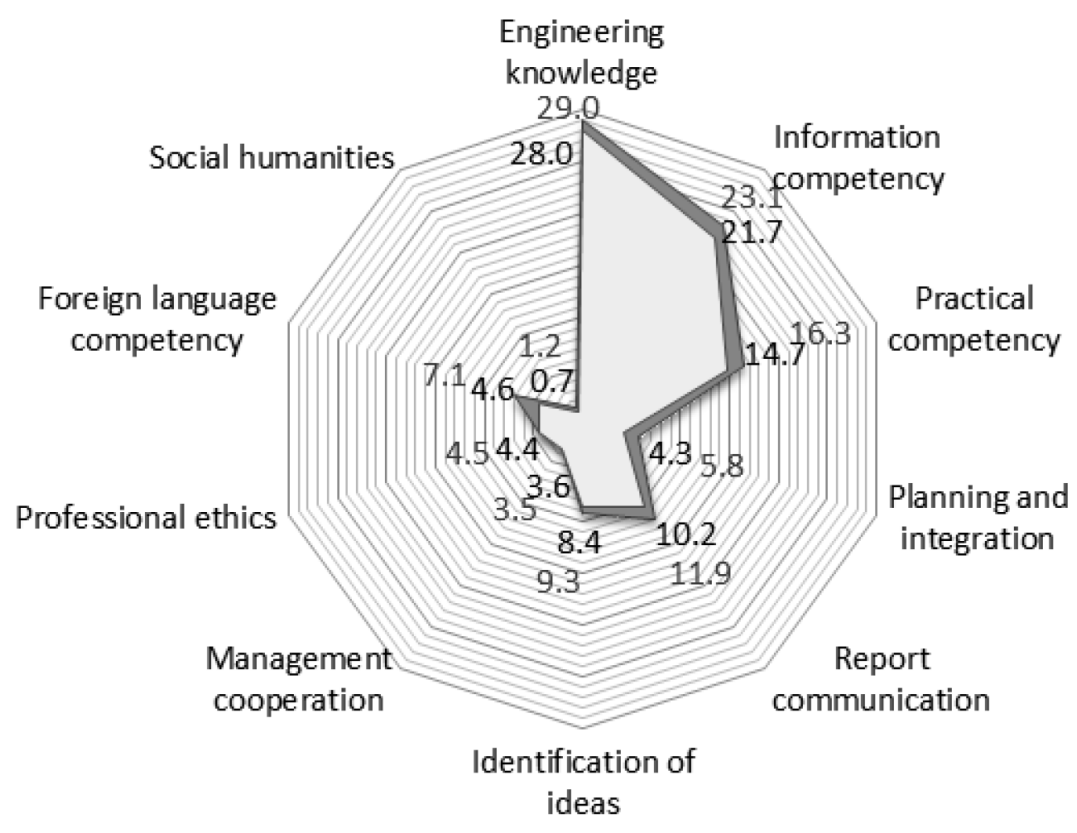

Figure 3. E-Map Weighting by learning hours of the student ranking first in class (black) and the other ranking fortieth in class (gray).

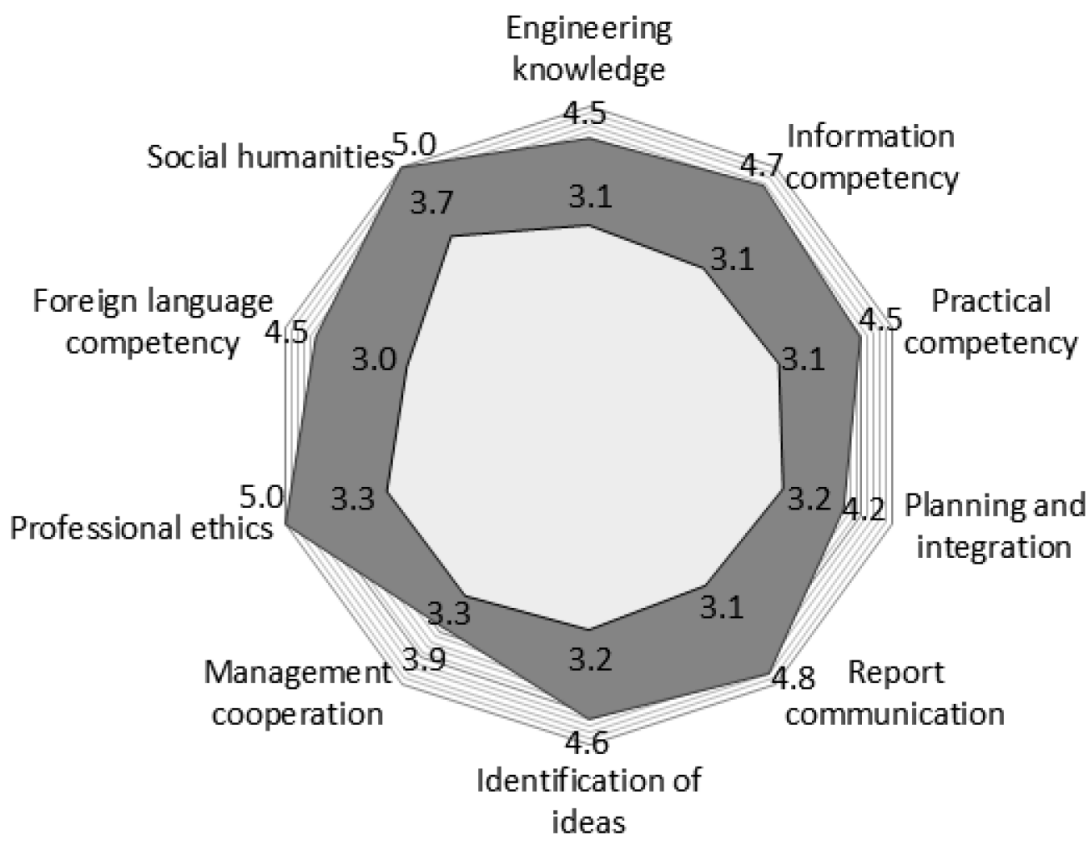

Figure 4. E-Map Weighting by learning achievement of the student ranking first in class (black) and the other ranking fortieth in class (gray). 
Shu-Chen CHENG, Shing-Lin CHANG. An innovative assessment method to establish employability map based on students' learning portfolio

From Figure 3-4, the E-Map of weighting by learning achievement can reflect students' core competency performance better than the E-Map of weighting by learning hours.

\section{Experimental Design}

In this research, the graduating students from the university department, the alumni and the alumni's employers were adopted as research participants. Prior to graduation, the graduating students were requested to fill out a direct questionnaire on the respective core competencies in order for the students to examine the degree of core competency perceived in the past four years. In addition, based on courses taken and passed, the course questionnaire on the degree of course comprehension was filled out to test the various core competencies. The questionnaire courses were selected by the Course Committee from the subjects taken by the graduating students. As for the alumni, the samples consist of alumni who had graduated for 3-5 years, as the employment situation of the alumni at the time was considered more stable. The alumni were asked to evaluate the relevance between their current job and various competency items as well as their degree of perception towards the competency items provided through the department teaching over the course of their schooling. Finally, in the questionnaire for the employers of the alumni, the samples were obtained from the alumni who had graduated for 3-5 years, consisting of the employers of the alumni who underwent the survey through paper questionnaires, the Internet, or telephone interviews. The purpose of the survey was for the employers to evaluate the importance of the various competency items the company to and whether or not the alumni possess such competency. The samples were difficult to acquire, but the valid samples of the questionnaire for employers accumulated to 70 copies in three years.

In the research, SPSS 19.0 is used as the statistics analysis. Descriptive statistics, t-test, one-way ANOVA, and Scheffe multiple comparison procedures were employed to analyze the data.

\section{Research Results}

\section{Analysis of Questionnaire for Graduating Students}

The graduates of the university department were adopted as the survey participants. The direct questionnaires of respective core competencies and course development questions were corresponded to the course questionnaire of respective core competencies, with valid samples totaling 97. From these two types of questionnaires (See Table 5-6), findings show that all the items on mean (Mean) were passed (3 points) and the standard deviations $(S D)$ of all these core competencies were less than 1 . The reliability of self-assessed core competency of Cronbach's $\alpha=.922$ represents high reliability. Table 5 shows the students' direct self-assessment of their perception of foreign language competency is rather inadequate. However, the course questionnaire (See Table 6) showed the weighted average of foreign language competency reaches 3.78 points on average, an indication that the students underestimated their foreign language competency. 
Shu-Chen CHENG, Shing-Lin CHANG. An innovative assessment method to establish employability map based on students' learning portfolio

OF EDUCAT IN THE $21^{\text {st }}$ CENTURY Vol. 77 , No. 1, 2019

Table 5. Core competency values in the direct questionnaire for graduating students.

\begin{tabular}{lcccccccccc}
\hline $\begin{array}{l}\text { Core compe- } \\
\text { tency }\end{array}$ & E.K. & I.C. & P.C. & P.I. & R.C. & I.I. & M.C. & P.E. & F.L.C. & S.H. \\
\hline Mean & 3.47 & 3.56 & 3.56 & 3.50 & 3.45 & 3.51 & 3.58 & 3.79 & 3.17 & 3.62 \\
\hline$S D$ & 0.83 & 0.87 & 0.88 & 0.90 & 0.95 & 0.90 & 0.99 & 0.86 & 0.88 & 0.78 \\
\hline
\end{tabular}

Table 6. Core competency values corresponding to the course questionnaire for graduating students.

\begin{tabular}{lllllllllll}
\hline $\begin{array}{l}\text { Core compe- } \\
\text { tency }\end{array}$ & E.K. & I.C. & P.C. & P.I. & R.C. & I.I. & M.C. & P.E. & F.L.C. & S.H. \\
\hline Mean & 3.75 & 3.76 & 3.78 & 3.75 & 3.83 & 3.78 & 3.82 & 3.88 & 3.78 & 3.89 \\
\hline SD & 0.85 & 0.84 & 0.83 & 0.84 & 0.81 & 0.86 & 0.88 & 0.92 & 0.89 & 0.79 \\
\hline
\end{tabular}

Subsequently, hypothetical test for the above-mentioned difference of two population means was conducted using t-distribution (See Table 7). With the difference in means test value of 0 , it shows that the weighted average by the course questionnaire is higher than that of the direct questionnaire. Moreover, other than information competency and professional ethics, the average of the remaining course questionnaires of core competency was significantly higher than that of the direct questionnaire $(p<.05)$. This finding shows that the various competencies were underestimated in the students' self-assessment, or the course questionnaire we designed was overestimated, especially in terms of engineering knowledge, report communication, and foreign language competency $(p<.01)$. Therefore, the department needs to discuss the reason contributing to the students' self-assessed lack of confidence, how to reinforce professional courses to make up for the vastly lagging core competency, whether the course questionnaire selection and content are appropriate, and so on. Based on the data, the department shall make adjustments as to the depth of course content or course hours.

Table 7. The difference between two population means tested in the questionnaire for graduating students.

\begin{tabular}{lllllllllll}
\hline $\begin{array}{l}\text { Core compe- } \\
\text { tency }\end{array}$ & E.K. & I.C. & P.C. & P.I. & R.C. & I.I. & M.C. & P.E. & F.L.C. & S.H. \\
\hline $\begin{array}{l}\text { Difference in } \\
\text { means }\end{array}$ & 0.273 & 0.197 & 0.219 & 0.249 & 0.383 & 0.272 & 0.240 & 0.085 & 0.612 & 0.274 \\
\hline $\begin{array}{l}p \text {-value (two- } \\
\text { tailed) }\end{array}$ & 0.006 & 0.054 & 0.036 & 0.027 & 0.001 & 0.016 & 0.024 & 0.479 & 0.000 & 0.015 \\
\hline
\end{tabular}

Here, it is explained this method's effectiveness for graduating students. There were three groups which were divided according to the students' graduating-total-average, in which the first $32 \%$ is the high achievement group (HAG), the $32 \%$ following to the lower achievement group (LAG), and the rest is the middle achievement group (MAG), respectively. Table 8 shows the means, standard deviations (SD) and one-way ANOVA of three groups at each core competency and their average of graduating-score. The means of graduating-score in the three groups had 
Shu-Chen CHENG, Shing-Lin CHANG. An innovative assessment method to establish employability map based on students' learning portfolio

significant differences $(F=172.05 ; p<.001)$. The means of core competency values in the three groups, except S.H., have significant differences (F.L.C., $p<.05$; rest $p<.001$ ). Using Scheffe multiple comparison procedures, the three groups HAG, MAG, and LAG have significant differences on graduating-score, P.C., and R.C. The other core competency, except S.H., HAG is significantly higher than LAG. Therefore, using learning achievement as weighting can reflect students' graduating-score, and core employment competency better.

Table 8. Means, SD and one-way ANOVA of three groups of students' achievements.

\begin{tabular}{|c|c|c|c|c|c|}
\hline $\begin{array}{l}\text { Core } \\
\text { competency }\end{array}$ & $\begin{array}{l}\text { HAG } \\
\text { Mean (SD) }\end{array}$ & $\begin{array}{l}\text { MAG } \\
\text { Mean (SD) }\end{array}$ & $\begin{array}{l}\text { LAG } \\
\text { Mean (SD) }\end{array}$ & $F$ & $\begin{array}{l}\text { Scheffe } \\
\text { Comparison }\end{array}$ \\
\hline $\begin{array}{l}\text { Graduating- } \\
\text { score }\end{array}$ & $80.27(3.79)$ & $72.38(2.00)$ & $65.72(2.27)$ & $172.05^{\star \star \star}$ & $H A G>M A G>L A G$ \\
\hline E.K. & $3.98(.18)$ & $3.65(.20)$ & 3.53(.17) & $36.06^{* * *}$ & HAG>MAG; HAG>LAG \\
\hline I.C. & $4.00(.78)$ & 3.63(.89) & 3.65(.81) & $31.79^{* * *}$ & HAG>MAG; HAG>LAG \\
\hline P.C. & 4.02(.13) & $3.72(.14)$ & $3.57(.11)$ & $48.24^{* * *}$ & $H A G>M A G>L A G$ \\
\hline P.I. & $4.10(.02)$ & $3.61(.07)$ & $3.56(.06)$ & $162.23^{* \star \star}$ & HAG>MAG; HAG>LAG \\
\hline R.C. & $4.06(.06)$ & $3.84(.17)$ & $3.60(.14)$ & $32.24^{* \star *}$ & HAG>MAG> LAG \\
\hline I.I. & 4.05(.09) & $3.71(.22)$ & $3.60(.49)$ & $14.00^{* * *}$ & HAG>MAG; HAG>LAG \\
\hline M.C. & $3.98(.14)$ & $3.82(.27)$ & $3.65(.18)$ & $6.34^{* * *}$ & HAG>LAG \\
\hline P.E. & $4.09(.23)$ & 3.92(.22) & 3.63(.08) & $9.33^{\star * *}$ & HAG>LAG; MAG>LAG \\
\hline F.L.C. & $4.01(.11)$ & $3.79(.17)$ & $3.40(.24)$ & $11.99^{* \star}$ & HAG>LAG; MAG>LAG \\
\hline S.H. & $4.01(.06)$ & $3.87(.05)$ & $3.79(.16)$ & 3.61 & \\
\hline
\end{tabular}

\section{Analysis of Questionnaire for Alumni}

The samples of the questionnaire survey targeting alumni, who have graduated for 3-5 years. Targeting each core competency, the alumni were requested to evaluate the relevance of their current job and individual competency items and their degree of perception towards individual competency items provided through department teaching. Tables 9-10 show the mean values and standard deviations of the questionnaires administered to the alumni. Of the 111 valid samples, the mean values all reached above 3 points. As for work relevance, the reliability is Cronbach's $\alpha=.934$. Table shows a low degree of correlation between the nature of work and professional competency (the first four core competency items falling under 3.1 3.3 points), while the standard deviation is greater. This reflects the lesser correlation between the alumni's job and information engineering, which deserves discussions within the department with regard to whether or not the courses offered enable students to find jobs related to their major. As for whether or not department teaching provides core competencies, the reliability is Cronbach's $\alpha=.882$. Table 10 shows that the respective items are highly correlated, indicating the alumni's recognition of respective core competency teachings. However, the foreign language competency was relatively weaker. Targeting the said competency, the department makes up for the insufficiency by enhancing professional English and strengthening English teaching of professional courses.

\begin{tabular}{|l} 
PROBLEMS \\
OF EDUCATION \\
IN THE 21 $11^{\text {st }}$ CENTURY \\
Vol. 77, No. 1, 2019 \\
\hline 221
\end{tabular} 
Shu-Chen CHENG, Shing-Lin CHANG. An innovative assessment method to establish employability map based on students' learning portfolio

OF EDUCAT IN THE $21^{\text {st }}$ CENTURY Vol. 77 , No. 1, 2019

Table 9. Questionnaire of alumni's self-assessment of core competency related to work needs.

\begin{tabular}{lllllllllll}
$\begin{array}{l}\text { Core compe- } \\
\text { tency }\end{array}$ & E.K. & I.C. & P.C. & P.I. & R.C. & I.I. & M.C. & P.E. & F.L.C. & S.H. \\
\hline Mean & 3.14 & 3.17 & 3.28 & 3.18 & 3.56 & 3.58 & 3.67 & 3.60 & 3.31 & 3.55 \\
\hline$S D$ & 1.07 & 0.99 & 1.06 & 0.95 & 1.01 & 1.00 & 0.89 & 0.92 & 1.01 & 0.89 \\
\hline
\end{tabular}

Table 10. Questionnaire of alumni's core competencies developed from courses over the course of their schooling.

\begin{tabular}{lllllllllll}
\hline $\begin{array}{l}\text { Core compe- } \\
\text { tency }\end{array}$ & E.K. & I.C. & P.C. & P.I. & R.C. & I.I. & M.C. & P.E. & F.L.C. & S.H. \\
\hline Mean & 3.50 & 3.53 & 3.60 & 3.46 & 3.68 & 3.68 & 3.77 & 3.73 & 3.35 & 3.59 \\
\hline$S D$ & 0.81 & 0.75 & 0.89 & 0.80 & 0.82 & 0.79 & 0.70 & 0.73 & 0.84 & 0.78 \\
\hline
\end{tabular}

The test of the difference between two population means was performed using t-distribution (See Table 11), the tested difference in means was 0 . It is found that professional competency (engineering knowledge, information competency, practical competency, and planning integration) show significant differences $(p<.05)$, indicating the department's professional education meets the alumni's needs. However, if viewed from work profession relevance, the department may have to discuss whether or not the current courses can enhance students' employability in the information engineering category. It is recommended that emerging industry related courses be commenced to strengthen students' employment competency.

Table 11. The difference between two population means tested in the questionnaire for alumni.

\begin{tabular}{lllllllllll}
\hline $\begin{array}{l}\text { Core compe- } \\
\text { tency }\end{array}$ & E.K. & I.C. & P.C. & P.I. & R.C. & I.I. & M.C. & P.E. & F.L.C. & S.H. \\
\hline $\begin{array}{l}\text { Difference in } \\
\text { means }\end{array}$ & 0.360 & 0.360 & 0.324 & 0.279 & 0.117 & 0.108 & 0.108 & 0.126 & 0.045 & 0.036 \\
\hline $\begin{array}{l}p \text {-value (two- } \\
\text { tailed) }\end{array}$ & 0.005 & 0.002 & 0.014 & 0.018 & 0.343 & 0.370 & 0.313 & 0.257 & 0.718 & 0.749 \\
\hline
\end{tabular}

Analysis of Questionnaire for Employers

In recent years, many enterprises in Taiwan have expressed that students' skills and business do not match. Therefore, targeting the employers of alumni from the department, a survey was carried out. The samples comprised employers or supervisors of alumni who had graduated for 3-5 years. Targeting every core competency, the employers were requested to evaluate the importance of the respective competency items to the company (Cronbach's $\alpha=.774$ ) and whether or not the alumni possess such competencies (Cronbach's $\alpha=.891$ ). Tables 12-13 show the mean and standard deviation of the employers of alumni in recent years. There are 70 valid samples, all of which reach a mean of above 3.7 points. The standard deviation of the evaluation of whether or not the alumni possess the competencies is relatively low (Table 13). Obviously, most employers' recognition of the alumni's competency is positive and consistent. 
Shu-Chen CHENG, Shing-Lin CHANG. An innovative assessment method to establish employability map based on students' learning portfolio

Table 12. Evaluation of core competency demand by employers of alumni.

\begin{tabular}{lllllllllll}
\hline $\begin{array}{l}\text { Core compe- } \\
\text { tency }\end{array}$ & E.K. & I.C. & P.C. & P.I. & R.C. & I.I. & M.C. & P.E. & F.L.C. & S.H. \\
\hline Mean & 3.84 & 3.84 & 3.94 & 3.91 & 4.34 & 4.36 & 4.43 & 4.29 & 3.71 & 4.21 \\
\hline$S D$ & 1.07 & 1.09 & 1.01 & 0.97 & 0.74 & 0.90 & 0.63 & 0.80 & 0.73 & 0.88 \\
\hline
\end{tabular}

Table 13. Evaluation of whether alumni possess various core competencies by employers of alumni.

\begin{tabular}{lllllllllll}
\hline $\begin{array}{l}\text { Core compe- } \\
\text { tency }\end{array}$ & E.K. & I.C. & P.C. & P.I. & R.C. & I.I. & M.C. & P.E. & F.L.C. & S.H. \\
\hline Mean & 3.86 & 3.81 & 3.99 & 3.79 & 4.04 & 4.04 & 4.04 & 4.20 & 3.73 & 3.99 \\
\hline$S D$ & 0.60 & 0.64 & 0.69 & 0.68 & 0.73 & 0.62 & 0.77 & 0.65 & 0.74 & 0.67 \\
\hline
\end{tabular}

In the test of the difference between two population means using t-distribution (Table 14), the tested difference in means is 0 , and report communication, identification of ideas, and management cooperation reach significant differences $(p<.05)$. Since the difference in means is a negative value, the department needs to strengthen and review these aspects in order to meet employers' needs.

Table 14. The difference between two population means tested in the questionnaire for employers of alumni.

\begin{tabular}{lllllllllll}
\hline Core competency & E.K. & I.C. & P.C. & P.I. & R.C. & I.I. & M.C. & P.E. & F.L.C. & S.H. \\
\hline Difference in means & 0.014 & -0.029 & 0.043 & -0.129 & -0.300 & -0.314 & -0.386 & -0.086 & 0.014 & -0.229 \\
\hline$p$-value (two- tailed) & 0.922 & 0.850 & 0.769 & 0.367 & 0.017 & 0.022 & 0.001 & 0.488 & 0.908 & 0.087 \\
\hline
\end{tabular}

From the comparison of Table 9 and 12, it shows that core competencies demanded by employers are higher than those self-evaluated by the alumni (See Figure 5). Table 13 shows that employers' evaluation for the respective core competencies of alumni is higher than the alumni's self-assessment (See Table 9). Clearly, the alumni lack self-confidence, which is worthy of further discussion by the department. 
Shu-Chen CHENG, Shing-Lin CHANG. An innovative assessment method to establish employability map based on students' learning portfolio

PROBLEMS

OF EDUCATION

IN THE $21^{\text {st }}$ CENTURY

Vol. 77, No. 1, 2019

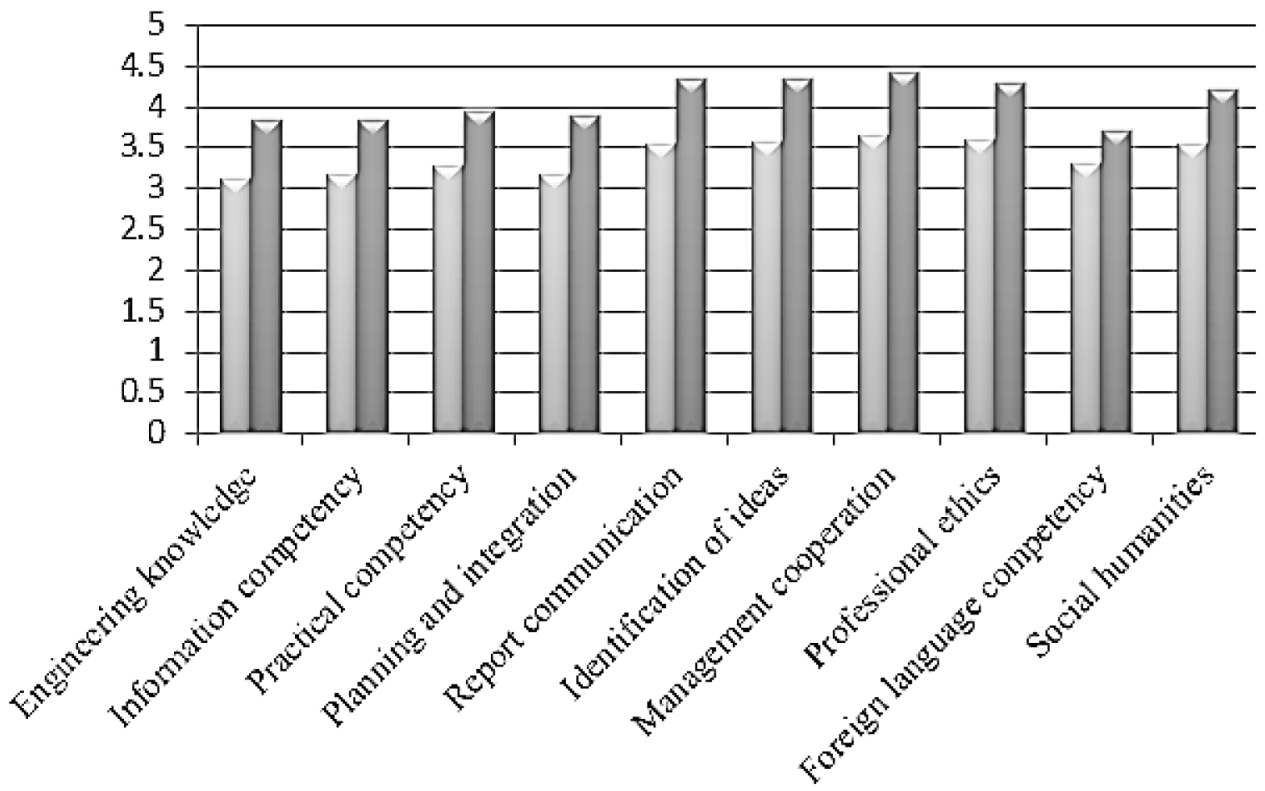

Figure 5. Work demand for core competency evaluated by alumni (gray) and employers of alumni (black).

\section{Discussion}

Generally, employability-related researches use direct self-assessment questionnaires for students. For example, Jackson (2014) researched the employability skill in higher education using student's self-assessment. Wu, Tsai, \& Chen (2014) used the direct questionnaire survey to examine career guidance, vocational self-concept and self-perceived employability from the science education majors' experience. In this research, using the course questionnaire with Equation 3 to obtain all core employment competency can reflect E-Map of employability indices better.

From employer's perspective, employees require not only professional competency, but also general knowledge competency or so-called soft skills to enhance their employability (Zubaidah \& Rugayah, 2008). Among these relevant soft skills, most researched showed that the highest demand was communication skills (Azian \& Mun, 2011; Billing, 2003; Abdul Hamid, Islam, \& Noor Hazilah, 2014; Rahmah, Ishak, \& Wei Sieng, 2011; Rasul, Ismail, Ismail, Rajuddin, \& Rauf, 2010; Zubaidah \& Rugayah, 2008). This was supported from Table 12, first and second core competency demanded by employers of alumni to soft skills were management cooperation and report communication, these were highly related with communication skills in this paper defined (See Table 1).

\section{Conclusions}

The credits earned by the students after taking and passing the courses may be used to serve as employability indices. The students may gain an insight into the learning effectiveness of various employment competency items through the employability radar chart weighting by learning hours, which shall serve as a reference during course planning and self-cognition. This information may also be provided to the department as a reference during course inspection and revision. However, this method is less capable of reflecting differences among students in terms 
of their learning ability. An E-Map adopting the course questionnaire, which is then converted to correspond to respective core competency items is proposed. Based on the courses taken and passed by the students, the students filled out a questionnaire according to their perceptions. Then, the core competencies obtained from the course training were distributed and statistical analysis was conducted on the core competencies corresponding to these subjects. The students may objectively view their employability learning effectiveness through the E-Map weighting by learning achievement. This presentation can reflect students' core employment competency better.

Core competency index questionnaires and assessments by three parties: graduating students, alumni, and employers of alumni were carried out. Using the direct questionnaire and the course questionnaire administered for the graduating students to inspect the core employability, the differences among the core competencies were compared, which reflected the graduating students' individual differences and learning conditions. As for the alumni, the demand for core competency from their current job and the alumni's degree of perception towards the competencies provided by department teaching over the course of their schooling were evaluated, which show the relevance between the alumni's knowledge learned at the time and the current industry. As for the employers of the alumni, the company's demand for respective core competencies and whether or not the alumni possess the respective core competencies are evaluated. The data was analyzed to provide the mean values of respective core competencies. Additionally, the core competencies showing significant differences were discussed at the department's expert consultation meetings to decide which areas need strengthening courses and reviews. The course contents, levels, and learning hours were adjusted to ensure the students achieve better employment competency and meet companies' needs.

The study showed that mean values of all items were greater than 3 and the standard deviations of all these core competencies were less than 1 from the direct questionnaire and the course questionnaire for graduating students. Additionally, it showed that all of the core competencies from the course questionnaire were higher than those from the direct questionnaire. Moreover, except information competency and professional ethics, the mean of core competencies of the remaining course questionnaires was significantly higher than that of the direct questionnaire. This finding showed that the various competencies were either underestimated in the students' self-assessment or overestimated from the course questionnaire. Therefore, the department needs to discuss the reason contributing to the students' lack of selfconfidence.

For alumni's questionnaire, the mean values of all items were greater than 3 and the standard deviations of all these core competencies were less than 1.07 from the relevance of their current job and their degree of perception provided through department teaching. As for work relevance, it shows a low degree of correlation between work needs and professional competency. This reflects a less correlation between the alumni's job and information engineering, which deserves discussions within the department with regard to whether or not the courses offered enable students to find jobs related to their major. Considering whether department teaching provides core competencies, the research found that all items were highly correlated, indicating the alumni's recognition of respective teachings for core competency. The difference between two population means was inspected and it is found that professional competency (except identification of ideas) showed significant differences, indicating the department's professional education meets the alumni's needs.

For the questionnaire of employers of alumni, the mean values of all items were greater than 3.7 and the standard deviations of all these core competencies were less than 1.09 from the demand of alumni's job and their competency. But the standard deviation of the evaluation of whether or not the alumni possess the competencies was less than 0.77 . Obviously, most employers' recognition of the alumni's competency was positive and consistent. The difference 
Shu-Chen CHENG, Shing-Lin CHANG. An innovative assessment method to establish employability map based on students' learning portfolio

\author{
PROBLEMS \\ OF EDUCATION \\ IN THE $21^{\text {st }}$ CENTURY \\ Vol. 77 , No. 1, 2019 \\ 226 between two population means was inspected and it is found that report communication, \\ identification of ideas, and management cooperation reached significant differences. Since the \\ difference in means is a negative value, the department needs to review and strengthen courses \\ in these aspects in order to meet employers' needs.
}

\title{
References
}

Abdul Hamid, M.S., Islam, R., \& Noor Hazilah, A.M. (2014). Malaysian graduates' employability skills enhancement: an application of the importance performance analysis. Journal for Global Business Advancement, 7(3), 181-197.

Alana, S. (2016). Online available from https://www.theatlantic.com/business/archive/2016/10/whyeconomic-growth-is-so-lackluster/504989/.

Azian, H., \& Mun, L.Y. (2011). English work: top jobs only for those who know the language well. The Star, 10 April, 1-5.

Beveridge, W. H. (1909). Unemployment: A Problem of Industry. London: Longmans, Green.

Billing, D. (2003). Generic cognitive abilities in higher education: An international analysis of skill sought by stakeholders. Compare, 33, 335-350.

Guilbert, L., Bernaud, J.-L., Gouvernet, B., \& Rossier, J. (2016). Employability: Review and research prospects. International Journal for Educational and Vocational Guidance, 16(1), 69-89.

Harvey, L. (2005). Embedding and integrating employability. New Directions for Institutional Research, $128,13-28$

Harvey, L., Locke, W., \& Morey, A. (2002). Enhancing employability, recognizing diversity. London: Universities UK and CSU.

Holmes, L. (2006). Reconsidering graduate employability: Beyond possessive-instrumentalism. Paper presented at the seventh International Conference on HRD Research and Practice across Europe, Tilburg, Netherlands.

Hugh-Jones, S., Sutherland, E., \& Cross, A. (2006). The graduate: Are we giving employers what they want?. Paper presented at the Teaching and Learning Conference. In Leeds, UK.

Institute of Engineering Education Taiwan (IEET) (2018). Online available from https://www.ieet.org. tw/en/

Jackson, D. (2014). Self-assessment of employability skill outcomes among undergraduates and alignment with academic ratings. Assessment \& Evaluation in Higher Education, 39(1), 53-72.

Rae, D. (2007). Connecting enterprise and graduate employability: Challenges to the higher education culture and curriculum? Education+Training, 49(8/9), 605-619.

Rahmah, I., Ishak, Y. \& Wei Sieng, L. (2011). Employers' perception on graduates in Malaysia service sector. International Business Management, 5(3), 184-193.

Rasul, M.S., Ismail, M.Y., Ismail, N., Rajuddin, M.R. \& Rauf, R.A.A. (2010). Development of employability skills assessment tool for manufacturing industry. Jurnal Mekanikal, 30, 4-61.

Rothwell, A., \& Arnold, J. (2007). Self-perceived employability: Development and validation of a scale. Personnel Review, 36(1), 23-41.

Tholen, G. (2015). What can research into graduate employability tell us about agency and structure? British Journal of Sociology of Education, 36(5), 766-784.

Turner, N. K. (2014). Development of self-belief for employability in higher education: Ability, efficacy and control in context. Teaching in Higher Education, 19(6), 592-602.

Tymon, A. (2013). The student perspective on employability. Studies in Higher Education, 38(6), 841856.

Wu, Y. L., Tsai, Y. L. \& Chen, C. W., (2014). Examining the experiences of career guidance, vocational self-concept, and self-perceived employability among science education majors in Taiwan. Journal of Baltic Science Education, 13(2), 182-190.

Yorke, M. (2004). Employability in the undergraduate curriculum: Some student perspectives. European Journal of Education, 39(4), 409-427. 
Shu-Chen CHENG, Shing-Lin CHANG. An innovative assessment method to establish employability map based on students' learning portfolio

PROBLEMS

OF EDUCATION

IN THE $21^{\text {st }}$ CENTURY

Vol. 77, No. 1, 2019

Zubaidah, A. \& Rugayah, M. (2008). Imperative attributes for graduate employability in manufacturing firms: issues for internationalising Malaysia's curricula, in Sarjit, K., Morshidi, K. and Norzaini, A. (Eds.): Globalization and Internationalisation of Higher Education in Malaysia, Penerbit UniversitiSains Malaysia, Pulau Pinang, 245-260.

Received: February 01, 2019

Accepted: April 05, 2019

\begin{tabular}{|c|c|}
\hline Shu-Chen Cheng & $\begin{array}{l}\text { Associate Professor, Department of Computer Science and Information Engi- } \\
\text { neering, Southern Taiwan University of Science and Technology, No. 1, Nan- } \\
\text { Tai Street, Yongkang Dist., Tainan City 710, Taiwan. } \\
\text { E-mail: kittyc@stust.edu.tw } \\
\text { Website: http://ilearning.csie.stust.edu.tw }\end{array}$ \\
\hline $\begin{array}{l}\text { Shing-Lin Chang } \\
\text { (Corresponding author) }\end{array}$ & $\begin{array}{l}\text { Professor, Department of Computer Science and Information Engineer- } \\
\text { ing, Southern Taiwan University of Science and Technology, No. 1, Nan-Tai } \\
\text { Street, Yongkang Dist., Tainan City 710, Taiwan. } \\
\text { E-mail: slchang@stust.edu.tw } \\
\text { Website: https://csie.stust.edu.tw/tc/node/Teacher3 }\end{array}$ \\
\hline
\end{tabular}

